\title{
Assessment of the risk of colorectal cancer in Poland on the basis of the analysis of epidemiological indicators
}

\section{Ocena zagrożenia rakiem jelita grubego w Polsce na podstawie analizy współczynników epidemiologicznych}

\author{
Grażyna R. Wiraszka1, Maciej Kielar², Renata B. Stępień² \\ 'Department of Internal Diseases, Cardiology and Medicine Nursing, Institute of Nursing and Obstetrics, Faculty of Health Sciences, \\ Jan Kochanowski University, Kielce, Poland \\ Head of the Department: Prof. Marianna Janion MD, PhD \\ 2Department of Oncology and Nursing Oncology, Institute of Nursing and Obstetrics, Faculty of Health Sciences, Jan Kochanowski \\ University, Kielce, Poland \\ Head of the Department: Prof. JKU Maciej Kielar MD, PhD
}

Key words: colorectal cancer, incidence, mortality, prevention.

Słowa kluczowe: rak jelita grubego, zachorowalność, umieralność, profilaktyka.

\begin{abstract}
Malignant tumours are one of the leading causes of death, as well as one of the most important health problems, in Poland and worldwide. Aim of the research was to assess the risk of colorectal cancer in a population of men and women in Poland based on the analysis of data from the most recent studies and epidemiological sources, particularly from the National Cancer Registry. In this study, epidemiological indicators of incidence and deaths for general colorectal cancer (ICD-10: C18-C21) as well as for particular cancer locations (C18 - colon, C19 - rectosigmoid junction, C20 - rectum, C21 - anus and anal canal) analized in men and women in Poland in 2011 as well as the profile of these parameters in years 1999-2011. The incidence for colorectal cancer (CRC) in man: structure indicators (SI) - 12.4\%, age standardized rates (ASR) - 30.2/105; in women: SI - 10.0\%, ASR - 18.0/105. The deaths due to CRC in men: SI - 11.4\%, ASR - 19.8/105; in women: SI - 11.8\%, ASR - 10.2/105. Colorectal cancer is a serious threat to the health of Poles, characterised by its dynamics increasing with population age, by high incidence and mortality, as well as by a persistent, constant tendency for increasing epidemiological rates, especially among men. The differentiation of epidemiological rates follows from tumour location. Higher incidence and mortality rates are registered for the population of men and among the residents of Western Poland.
\end{abstract}

\section{Streszczenie}

Nowotwory złośliwe stanowią główną przyczynę zgonów i jeden z najpoważniejszych problemów zdrowotnych zarówno na świecie, jak i w Polsce. Celem pracy była ocena zagrożenia rakiem jelita grubego u mężczyzn i kobiet w Polsce na podstawie analizy danych pochodzących z najnowszych opracowań i źródeł epidemiologicznych, głównie z Krajowego Rejestru Nowotworów. W pracy analizowano wskaźniki epidemiologiczne charakteryzujące zachorowania i zgony z powodu raka jelita grubego ogółem (ICD-10: C18-C21) oraz dla poszczególnych umiejscowień (C18 - okrężnica, C19 - zgięcie esiczo-odbytnicze, C20 - odbytnica, C21 - odbyt i kanał odbytu) u mężczyzn i kobiet w Polsce w 2011 r. oraz ich zachowanie się w latach 1999-2011. Zachorowania na raka jelita grubego w populacji mężczyzn przedstawiały się następująco: wskaźnik struktury - 12,4\%, standaryzowany współczynnik zapadalności - 30,2/105; a w populacji kobiet odpowiednio 10,0\% i 18,0/105. Zgony z powodu RJG w populacji mężczyzn: wskaźnik struktury - 11,4\%, współczynnik umieralności - 19,8/105; a w populacji kobiet odpowiednio 11,8\% i 10,2/105. Rak jelita grubego jest poważnym zagrożeniem dla zdrowia Polaków. Charakteryzuje się on rosnącą wraz z wiekiem populacji dynamiką, wysoką zachorowalnością i umieralnością oraz utrzymującą się, zwłaszcza wśród mężczyzn, stałą tendencją wzrostową wskaźników epidemiologicznych. Zróżnicowanie wskaźników epidemiologicznych wiąże się z lokalizacją nowotworu. Wyższe wskaźniki zachorowalności i umieralności odnotowuje się wśród mężczyzn oraz mieszkańców Polski Zachodniej. 


\section{Introduction}

Despite dynamic progress in medicine, including oncology, malignant tumours remain one of the main causes of high mortality, accounting for one of the most important health problems in Poland [1-4]. They are the second most common cause of death [1, 2] and the third most common cause of hospitalisation (9\%) [3]. In 2011, 26\% of deaths in men and 23\% of deaths in women were attributed to cancer. Taking into account the completeness of records, it is estimated that in 2011, cancer was diagnosed in about 154,000 individuals and more than 320,000 were surviving with cancer diagnosed in the preceding 5 years [2]. Malignant tumours are a significant threat to life, particularly in the male population [1, 2]. In 2011, the standardised incidence rate in men was 252/10 compared to $207 / 10^{5}$ in women. Mortality rates were also less favourable in men $\left(174 / 10^{5}\right)$ as compared to women $\left(98 / 10^{5}\right)[2]$. In addition, alarming prognoses predict an increase in the incidence and deaths due to malignant tumours in the following years $[5,6]$.

One of the most common malignant tumours worldwide, ranked between the second and the fourth most common in terms of incidence as well as deaths (8\%), is colorectal cancer [7-11]. According to GLOBOCAN (IARC) data for 2012, colorectal cancer was the cause of 746,000 new cancer cases in men (10.0\%) and 614,000 new cancer cases in women (9.2\%) worldwide, and of 694,000 deaths (overall) [10]. The incidence of colorectal cancer varies in various regions of the world. The highest incidence from colorectal cancer is observed in industrialised and economically developed countries $[9,10,12]$, where nearly $55 \%$ of cases are reported [10]. The disease is diagnosed less commonly in developing countries $[11,12]$. The highest incidence is observed in Australia, New Zealand, and Western Europe while the lowest incidence is observed in Africa and south-central Asia [11]. The relationship between the incidence and economic development is confirmed by the recently observed increase in the incidence of colorectal cancer in China [13]. In the US, colorectal cancer is the third most common cancer in terms of both incidence and mortality. In 2013, 142,820 new cancer cases and 50,830 deaths were reported there, accounting for $9 \%$ of all deaths due to malignant cancers [7]. In Poland, colorectal cancer was the cause of 10,820 deaths in the entire population in 2010 [1, 14], accounting for $12 \%$ of all cancer deaths [1]. The mortality rates for colorectal cancer in the years 1999-2011 were less favourable, compared to EU states [1], being approximately 50\% higher in men and slightly higher in women in 2010, compared to the EU average [11].

The goal of the study was to assess the risk of colorectal cancer in a population of men and women in Poland based on the analysis of data from the most recent studies and epidemiological sources, particularly from the National Cancer Registry.
The current cancer registry system in Poland is based on state-of-the-art information technology and provides reliable, high-quality data. The system consists of 16 voivodeship cancer registries that comprise a database for epidemiological analyses covering the entire territory of Poland [6].

In this study, epidemiological indicators of incidence and deaths for general colorectal cancer (ICD10: C18-C21) as well as for particular cancer locations (C18 - colon, C19 - rectosigmoid junction, C20 - rectum, C21 - anus and anal canal) in men and women in Poland in 2011, as well as the profile of these parameters in the years 1999-2011. The following indicators were applied: the absolute numbers of cancer cases (incidence cases or deaths) due to colorectal cancers in a particular period of time; the structure indicator - a quotient of the absolute number of registered cases (incidence cases or deaths) of a particular cancer and the total number of cases, expressed as a percentage value; and age standardised rate (ASR) of incidence (mortality) gives the number of cases (incidence cases or deaths) per 100,000 of the standard world population $[2,14,15]$.

\section{Incidence of colorectal cancer in Poland}

As shown by the data from the National Cancer Registry (NCR) [2, 11, 16] (Table 1), colorectal cancer was the third most common malignancy in males in 2011 (12.4\% of all new cancer cases) after lung cancer (20.2\%) and prostate cancer (14.4\%). In women, it was the second most common malignancy (after breast cancer $-22.8 \%$ ), accounting for $10 \%$ of all recorded cancer cases. As suggested by standard incidence rates, colorectal cancer is a higher threat to males $\left(30.2 / 10^{5}\right)$ as compared to females $\left(18.0 / 10^{5}\right)$, while the most common malignancy location in both groups was the colon (M: $16.3 / 10^{5}$, F: $\left.10.8 / 10^{5}\right)$.

The analysis of data on the location of malignancies in organ systems [2] revealed that in 2011 colorectal cancer comprised $53.7 \%$ of all new malignancies located within the gastrointestinal tract in males, as compared to $55.7 \%$ in females.

Colorectal cancer incidence levels differ in different regions of the country. As demonstrated by the National Cancer Registry data [2, 11, 16] presented in Table 2, colorectal cancer was the second most common cancer (more common than prostate cancer) in as many as 7 of 16 voivodeships in 2011. The percentage share in all cancer cases ranged from $11.2 \%$ (Łódzkie Voivodeship) to $17.4 \%$ (Podlaskie Voivodeship). Standardised incidence rate values suggest that in the year of interest, new cancer cases were most common in men in Kujawsko-Pomorskie Voivodeship $\left(37.2 / 10^{5}\right)$, Dolnośląskie Voivodeship $\left(35.5 / 10^{5}\right)$, and Wielkopolskie Voivodeship $\left(35.1 / 10^{5}\right)$, while being the least common in Mazowieckie Voivodeship (25.0/10 $)$ and Podlaskie Voivodeship $\left(25.1 / 10^{5}\right)$. In the group of 
Table 1. Main causes of cancer in Poland in 2011 (absolute numbers, structure indicators, age-standardised rates of incidence)

\begin{tabular}{|c|c|c|c|c|c|}
\hline Gender & Location & ICD 10 & $\begin{array}{l}\text { Absolute } \\
\text { numbers }\end{array}$ & $\begin{array}{c}\text { Structure } \\
\text { indicators (\%) }\end{array}$ & ASR/100,000 \\
\hline \multirow[t]{7}{*}{ Male } & Lung & C34 & 14522 & 20.2 & 50.0 \\
\hline & Prostate & C61 & 10318 & 14.4 & 35.1 \\
\hline & Large intestine: & C18-21 & 8880 & 12.4 & 30.2 \\
\hline & Colon & C18 & 4811 & 6.7 & 16.3 \\
\hline & Rectum & $\mathrm{C} 20$ & 3461 & 4.8 & 11.8 \\
\hline & Rectosigmoid junction & C19 & 549 & 0.76 & 1.9 \\
\hline & Anus & $\mathrm{C} 21$ & 59 & 0.1 & 0.2 \\
\hline \multirow[t]{7}{*}{ Female } & Breast & $\mathrm{C} 50$ & 16534 & 22.8 & 51.8 \\
\hline & Large intestine: & C18-21 & 7246 & 10.0 & 18.0 \\
\hline & Colon & C18 & 4381 & 6.0 & 10.8 \\
\hline & Rectum & $\mathrm{C} 20$ & 2247 & 3.1 & 5.6 \\
\hline & Rectosigmoid junction & C19 & 477 & 0.7 & 1.2 \\
\hline & Anus & $\mathrm{C} 21$ & 141 & 0.2 & 0.4 \\
\hline & Lung & C34 & 6283 & 8.7 & 17.2 \\
\hline
\end{tabular}

Own compilation of NCR data $[2,11,16]$.

Table 2. Incidence of colorectal cancer in men and women in Poland in 2011 (structure indicators, age-standardised rates)

\begin{tabular}{|c|c|c|c|c|}
\hline \multirow[t]{3}{*}{ Voivodeship } & \multicolumn{2}{|c|}{ Male } & \multicolumn{2}{|c|}{ Female } \\
\hline & $\begin{array}{c}\text { Structure } \\
\text { indicator (\%) }\end{array}$ & ASR/100,000 & $\begin{array}{c}\text { Structure } \\
\text { indicator (\%) }\end{array}$ & ASR/100,000 \\
\hline & /in descending order & & & \\
\hline Dolnośląskie & $13.2 /^{2}$ & $35.5 /^{2}$ & $10.8 /^{2}$ & $20.3 / 4$ \\
\hline Kujawsko-Pomorskie & $13.2 /^{2}$ & $37.2 /^{1}$ & $9.8 /^{2}$ & $19.1 /^{7}$ \\
\hline Lubelskie & $11.5 /^{3}$ & $29.1 / 9$ & $9.8 / 2$ & $16.8 / 12-13$ \\
\hline Lubuskie & $15.0 /^{3}$ & $34.2 /^{5}$ & $11.6 /^{2}$ & $21.2 /^{1}$ \\
\hline Łódzkie & $11.2 /^{3}$ & $28.4 / 12$ & $8.7 / 3$ & $15.0 / 15$ \\
\hline Małopolskie & $11.3 / 3$ & $26.8 /{ }^{14}$ & $9.6 / 2$ & $17.6 /{ }^{10}$ \\
\hline Mazowieckie & $12.3 / 3$ & $25.0 / 16$ & $9.5 / 2$ & $14.9 / 16$ \\
\hline Opolskie & $13.8 /{ }^{2}$ & $33.2 /^{6}$ & $10.1 /^{2}$ & $18.6 /^{8}$ \\
\hline Podkarpackie & $11.9 / 3$ & $28.8 / 11$ & $9.7 / 3$ & $16.8 / 12-13$ \\
\hline Podlaskie & $17.4 /^{2}$ & $25.1 /{ }^{15}$ & $10.8 / 2$ & $16.4 /{ }^{14}$ \\
\hline Pomorskie & $11.4 /^{3}$ & $33.0 /^{7}$ & $10.4 /^{2}$ & $21.1 /^{2}$ \\
\hline Śląskie & $12.1 /^{3}$ & $29.0 /{ }^{10}$ & $9.6 / 2$ & $17.1 /{ }^{11}$ \\
\hline Świętokrzyskie & $13.7 / 2$ & $34.5 / 4$ & $11.4 / 2$ & $19.6 /{ }^{6}$ \\
\hline Warmińsko-Mazurskie & $12.7 / 2$ & $31.0 / 8$ & $10.8 / 3$ & $20.1 / 5$ \\
\hline Wielkopolskie & $12.5 /{ }^{3}$ & $35.1 /^{3}$ & $9.9 / 2$ & $20.7 / 3$ \\
\hline Zachodniopomorskie & $13.9 / 2$ & $28.3 / 13$ & $10.7 / 3$ & $18.2 /^{9}$ \\
\hline Poland & 12.4 & 30.2 & 10.0 & 17.9 \\
\hline
\end{tabular}

Own compilation of NCR data $[2,11,16]$. 
women, colorectal cancer cases in four voivodeships followed a different profile that the all-country data, accounting for the third most common malignancy. In these regions, colorectal cancer accounted for $8.7 \%$ to $11.6 \%$ of malignancies, being more dominant in Lubuskie Voivodeship (11.6\%) and Świętokrzyskie Voivodeship (11.4\%), while accounting for the lowest percentage share in Łódzkie Voivodeship (8.7\%). The highest standardised incidence rates were observed among women of the Lubuskie Voivodeship (21.2/10 $)$ and Pomorskie Voivodeship $\left(21.1 / 10^{5}\right)$ while the lowest values were calculated for Mazowieckie Voivodeship (14.9/10 $)$ and Łódzkie Voivodeship (15.0/105).

The difference in the incidence of colorectal cancer is also associated with gender, population age, and malignancy location (Figures 1, 2) [2, 11, 16]. The peak incidence of general colorectal cancer both in males and females is registered for the age group of $70-79$ years. This is also the age group with the highest number of cases of colon cancer (C18) and rectal cancer (C20), both in women and men, and of rectosigmoid junction cancer (C19) in women. In case of other locations, most cases were observed in younger

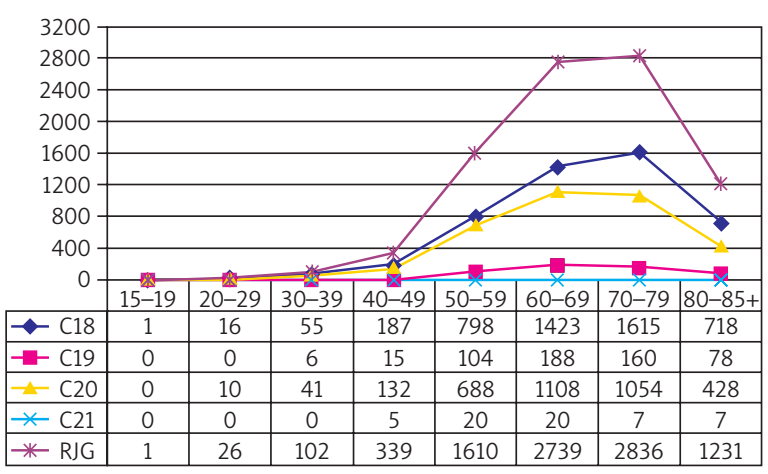

Figure 1. Incidence of CRC in males according to location and age (absolute numbers). Own compilation of NCR data $[2,11,16]$

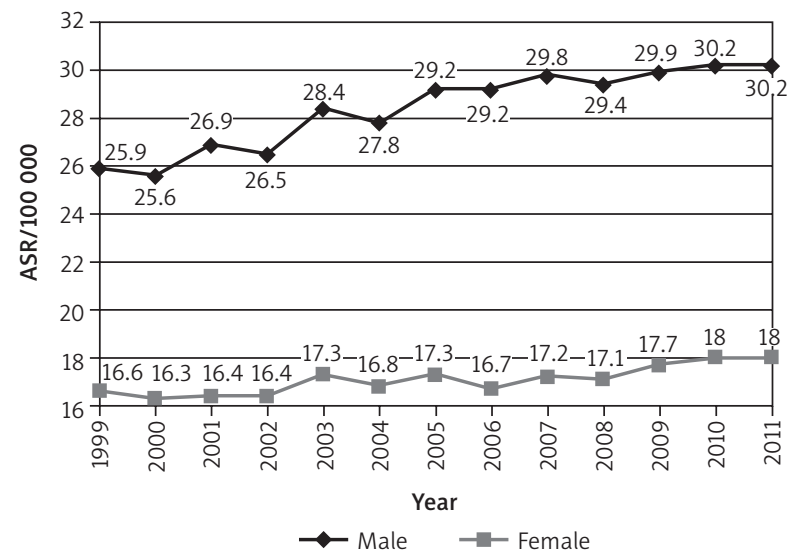

Figure 3. Incidence of colorectal cancer in men and women in Poland in the years 1999-2011 (age-standardised rates). Own compilation of NCR data $[11,16]$ age groups (females 50-59, males 60-69 years). As also shown by the data, most early cases of colorectal cancer (detected at the age of 15-19 years) were observed in the colon and, in the case of women, also in the rectum. Malignancies in other locations developed in older age groups.

The analysis of long-term epidemiological indicators (1999-2011) reveals a growing trend in colorectal cancer incidence (Figure 3). The trend is slight in the group of women $\left(16.6 / 10^{5}\right.$ to $\left.18.0 / 10^{5}\right)$ and larger in men $\left(25.9 / 10^{5}\right.$ to $\left.30.2 / 10^{5}\right)[11,16]$.

The analysis of data for years 1999 and 2011 for individual cancer locations (Figure 4) [11, 16] illustrates the growing trend for cases located within the colon (C18), rectosigmoid junction (C19), and anus (C20), in both men and women. The incidence of anal tumours (C21) is decreasing. In addition, a relatively large increase in the incidence of cases located within the rectosigmoid junction is of note.

Prognostic analyses for the coming years up to 2025 suggest that the trend towards increasing CRC incidence in Poland will remain on the increase. A rapid increase in incidence is predicted in males

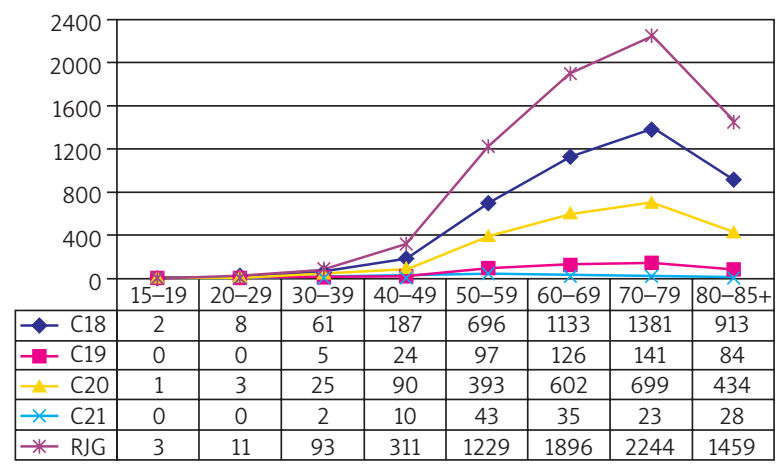

Figure 2. Incidence of CRC in females according to location and age (absolute numbers). Own compilation of NCR data $[2,11,16]$

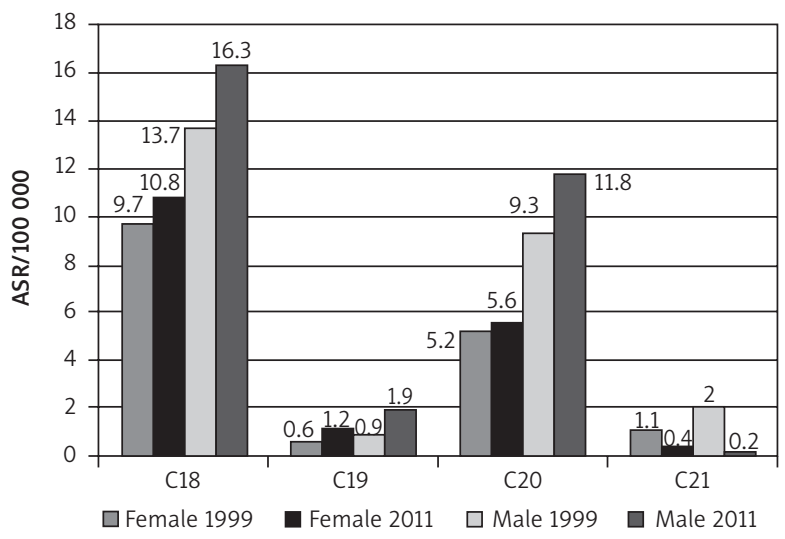

Figure 4. Incidence vs. locations of colorectal cancer in men and women in Poland in the years 1999-2011 (agestandardised rates). Own compilation of NCR data [11, 16] 
(particularly aged 45-64 and 65 years and over, as well as in the overall male population) compared to a slight increase in females [5].

\section{Deaths from colorectal cancer in Poland}

As demonstrated by the National Cancer Registry data $[2,11,16]$ (Table 3 ) colorectal cancer was the second most common cause of death in males (after lung cancer $-31 \%$ ), accounting for $11.4 \%$ of all deaths due to malignant tumours. In women, CRC was the third most common cause of cancer death (11.8\%), after lung cancer (15.4\%) and breast cancer (13.4\%). In 2011, deaths due to colorectal cancer were more common in males $\left(19.8 / 10^{5}\right)$ than in females $\left(10.2 / 10^{5}\right)$. The most common location of the tumour was the colon, both in men $\left(11.9 / 10^{5}\right)$ and in women $\left(6.79 / 10^{5}\right)$.

The analysis of data on the location of malignancies in organ systems [2, 11] revealed that in 2011, colorectal cancer comprised $39.8 \%$ of all deaths due to malignancies located within the gastrointestinal tract in males, as compared to $40.6 \%$ in females.

Data on deaths due to colorectal cancer recorded in Poland in 2011 reveal an uneven distribution of deaths in individual regions of Poland (Table 4) [2, $11,16]$. In males, CRC was the second most common cause of cancer deaths, ranging from 15.1\% (Opolskie Voivodeship) to $10 \%$ (Podkarpackie Voivodeship) of all deaths due to cancer. A similar distribution was observed for standardised mortality rates. The highest rate was calculated for Opolskie Voivodeship $\left(24.2 / 10^{5}\right)$ while the lowest was calculated for Pod- karpackie Voivodeship $\left(13.6 / 10^{5}\right)$. In women, on the other hand, colorectal cancer was the second most common cause of cancer-related deaths in three regions (Dolnośląskie Voivodeship, Podkarpackie Voivodeship, and Świętokrzyskie Voivodeship), in contrast to the overall national data. The highest rates were recorded in Opolskie Voivodeship (13.6\%) and Świętokrzyskie Voivodeship (13.4\%) while the lowest share was observed in Pomorskie Voivodeship $(10.3 \%)$. The standardised mortality rate was the highest for Lubuskie Voivodeship $\left(12.5 / 10^{5}\right)$ and the lowest for Podkarpackie Voivodeship $\left(7.8 / 10^{5}\right)$.

Variations in CRC mortality rates were also observed in relation to population age and tumour location $[2,11,16]$. The peak mortality rate in males for all tumour locations was reached in the age group of 7079 years. The earliest deaths were recorded in the age group of 25-29 years and were associated with colon (C18) or rectal (C20) location of the tumour (Figure 5).

In women the data were slightly different (Figure 6). The highest number of deaths for all locations (CRC) as well as for colon (C18) and anal (C 21) cancer was recorded in patients above 80 years of age. The earliest deaths were recorded in the age group of 2024 years and were associated with colon (C18) location of the tumour. The latest first deaths were recorded for anal cancer (C21) in the age group of 30-39 years.

The analysis of long-term data on deaths in the period 1999-2011 [11, 16] revealed a continuous increase in deaths due to colorectal cancer in males from $17.9 / 10^{5}$ to $20.1 / 10^{5}$ in 2010 and a slight drop to

Table 3. Main causes of deaths from cancer in Poland in 2011 (absolute numbers, structure indicators, age-standardised rates of mortality)

\begin{tabular}{|llcccc|}
\hline Gender & \multicolumn{1}{c}{ Location } & ICD 10 & $\begin{array}{c}\text { Absolute } \\
\text { numbers }\end{array}$ & $\begin{array}{c}\text { Structure } \\
\text { indicators (\%) }\end{array}$ & ASR/100,000 \\
& Lung & C34 & 15961 & 31.0 & 54.06 \\
& Large intestine: & C18-21 & 5876 & 11.4 & 19.18 \\
& Colon & C18 & 3675 & 7.13 & 11.9 \\
& Rectum & C20 & 1842 & 3.57 & 6.1 \\
& Rectosigmoid junction & C19 & 216 & 0.42 & 0.7 \\
& Anus & C21 & 143 & 0.28 & 0.48 \\
& Prostate & C61 & 4085 & 7.9 & 12.51 \\
& Breast & C50 & 5437 & 13.4 & 14.19 \\
& Large intestine: & C18-21 & 4787 & 11.8 & 10.2 \\
& Colon & C18 & 3213 & 7.91 & 6.79 \\
& Rectum & C20 & 1275 & 3.14 & 2.73 \\
& Rectosigmoid junction & C19 & 173 & 0.43 & 0.41 \\
& Anus & C21 & 126 & 0.31 & 0.25 \\
& Lung & C34 & 6255 & 15.4 & 16.21 \\
\hline
\end{tabular}

Own compilation of NCR data $[2,11,16]$. 
Table 4. Deaths due to colorectal cancer in men and women in Poland in 2011 (structure indicators, age-standardised rates of mortality)

\begin{tabular}{|c|c|c|c|c|}
\hline \multirow[t]{3}{*}{ Voivodeship } & \multicolumn{2}{|c|}{ Male } & \multicolumn{2}{|c|}{ Female } \\
\hline & $\begin{array}{c}\text { Structure } \\
\text { indicators (\%) }\end{array}$ & ASR $/ 100,000$ & $\begin{array}{c}\text { Structure } \\
\text { indicators (\%) }\end{array}$ & ASR $/ 100,000$ \\
\hline & /in descending order & & & \\
\hline Dolnośląskie & $10.7 / 2$ & $19.0 /{ }^{11}$ & $12.2 /^{2}$ & $11.2 /^{3}$ \\
\hline Kujawsko-Pomorskie & $11.2 / 2$ & $20.1 / 4-5$ & $11.4 /^{3}$ & $10.6 / 6-8$ \\
\hline Lubelskie & $11.6 / /^{2}$ & $18.4 /{ }^{13}$ & $12.3 /{ }^{3}$ & $8.5 /^{15}$ \\
\hline Lubuskie & $12.4 /^{2}$ & $23.7 / 2$ & $12.7 / 3$ & $12.5 /^{1}$ \\
\hline Łódzkie & $11.5 / 2$ & $19.6 / /^{7}$ & $11.9 / 3$ & $10.6 / 6-8$ \\
\hline Małopolskie & $11.3 / 2$ & $18.5 / 12$ & $11.9 / 3$ & $9.4 / 12$ \\
\hline Mazowieckie & $10.7 / 2$ & $17.3 /{ }^{14}$ & $11.0 /{ }^{3}$ & $9.2 / 13$ \\
\hline Opolskie & $15.1 / 2$ & $24.2 /^{1}$ & $13.6 / 3$ & $10.3 /{ }^{10}$ \\
\hline Podkarpackie & $10.0 / 2$ & $13.6 / 16$ & $11.4 / 2$ & $7.8 / 16$ \\
\hline Podlaskie & $11.5 / 2$ & $17.2 /{ }^{15}$ & $11.8 /{ }^{3}$ & $9.1 /^{14}$ \\
\hline Pomorskie & $10.7 / 2$ & $19.3 / 8-9$ & $10.3 / 3$ & $10.4 / 9$ \\
\hline Śląskie & $11.8 / 2$ & $20.1 / 4-5$ & $12.0 / 3$ & $11.0 / 4-5$ \\
\hline Świętokrzyskie & $12.2 /^{2}$ & $19.3 / /^{8-9}$ & $13.4 / 2$ & $9.6 / 11$ \\
\hline Warmińsko-Mazurskie & $11.2 /^{2}$ & $19.7 / /^{6}$ & $12.3 /{ }^{3}$ & $10.6 / 6-8$ \\
\hline Wielkopolskie & $12.5 / 2$ & $22.5 / 3$ & $12.1 / 3$ & $11.3 / 2$ \\
\hline Zachodniopomorskie & $10.7 / 2$ & $19.2^{10}$ & $11.1^{3}$ & $11.0 / 4-5$ \\
\hline Poland & 11.4 & 19.18 & 11.8 & 10.2 \\
\hline
\end{tabular}

Own compilation of NCR data $[2,11,16]$.

$19.2 / 10^{5}$ in 2011 . In the group of women, a constant diminishing trend was observed following an initial period of growth (Figure 7).

Data on deaths due to CRC in individual locations in the years 1999 and 2011 [11, 16] revealed a slightly increasing trend for deaths due to colon tumours (C18) as well as a more significant increasing trend (by ca. 100\%) for deaths due to rectosigmoid junction

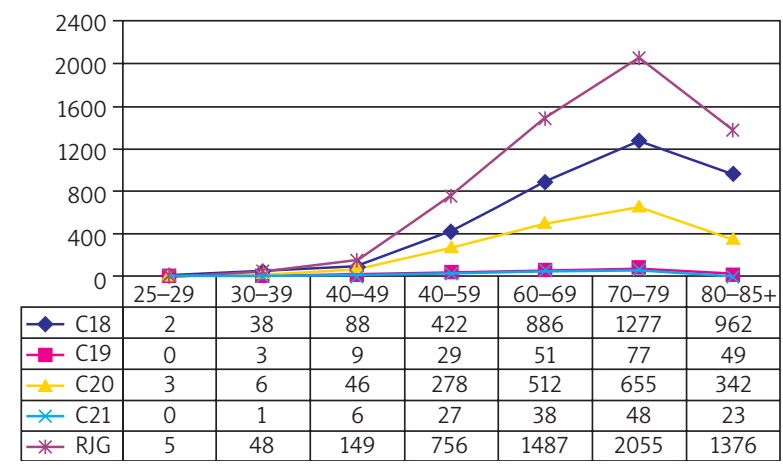

Figure 5. Number of deaths from CRC in males according to location and age. Own compilation of NCR data $[2,11,16]$ tumours (C19). In males, a growing trend (ca. 50\%) was also observed for rectal tumour location (C20). In both gender groups, quite significant reduction in mortality rates was observed in relation to anal tumour location (C21) (Figure 8).

Prognoses for the year 2025 suggest a continued and rapid increase in mortality rates in males, both overall as well as in the age groups of 45-64 years and

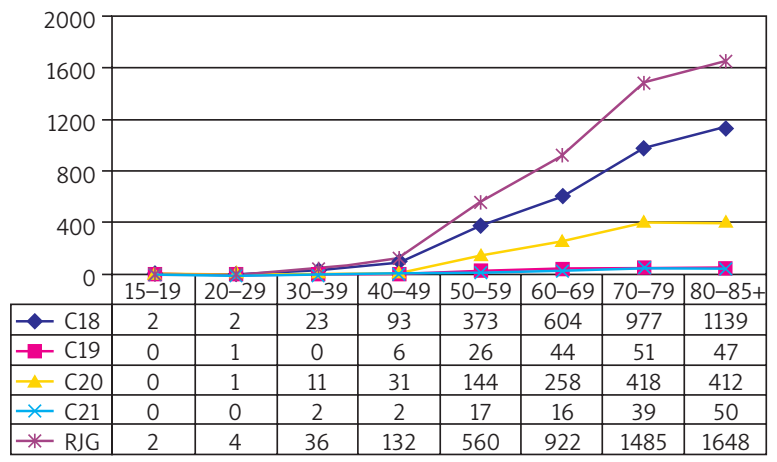

Figure 6. Number of deaths from CRC in females according to location and age. Own compilation of NCR data [2, $11,16]$ 


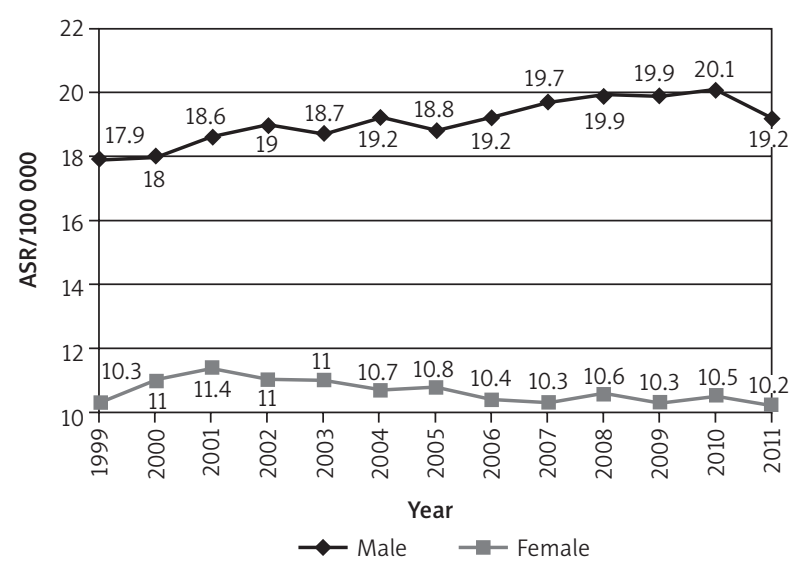

Figure 7. Deaths due to colorectal cancer in men and women in Poland in the years 1999-2011 (age-standardised rates of mortality). Own compilation of NCR data $[11,16]$

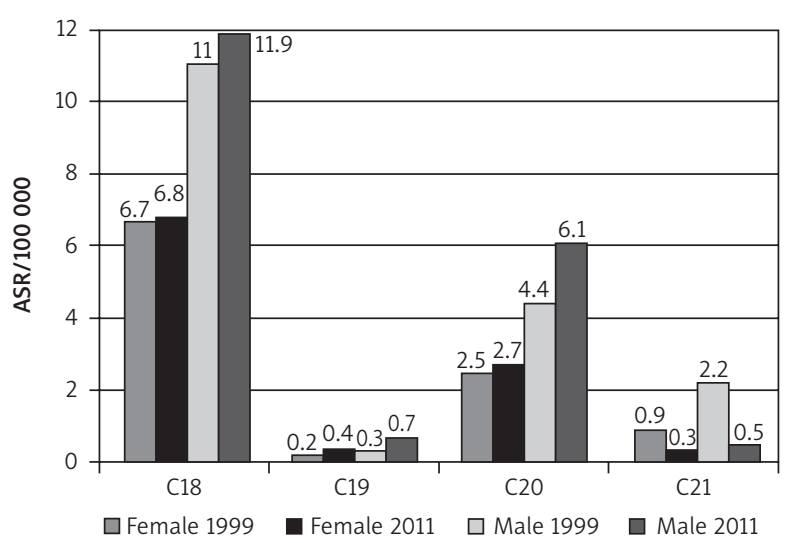

Figure 8. Deaths vs. locations of colorectal cancer in men and women in Poland in the years 1999-2011 (age-standardised rates of mortality). Own compilation of NCR data $[11,16]$

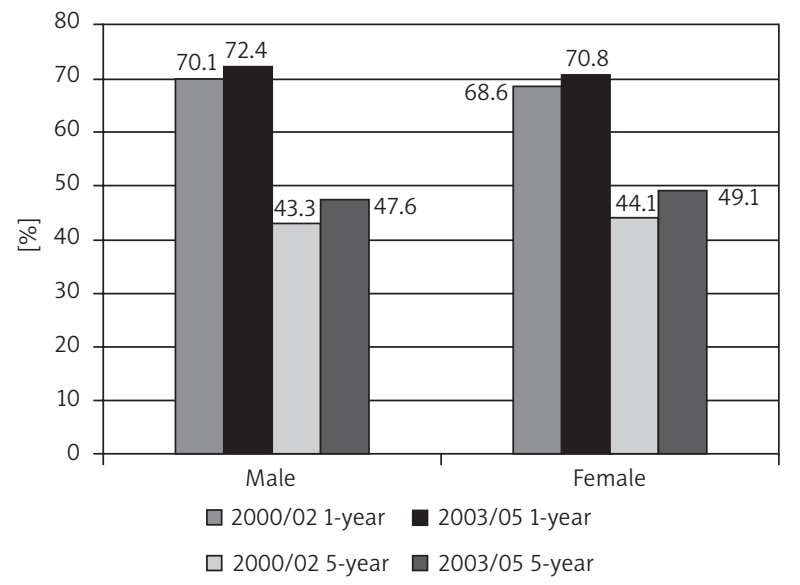

Figure 9. Survival of patients treated for CRC in Poland. Own compilation of NCR data $[2,11,17]$
65 years and over. In women, a continued decrease in mortality is predicted [5].

\section{Survival rates}

The -year and 5-year survival rates in patients diagnosed with colorectal cancer are unfavourable, despite having improved in the years 2003-2005 as compared to years 2000-2002 (Figure 9). Slightly more than 70\% of patients diagnosed in the years 2003-2005 survived for 1 year, the percentage being slightly higher in men. Significantly lower numbers, i.e. less than half of patients, survived for 5 years. Lower survival rates were observed in men (47.6\%) as compared to women $(49.1 \%)[2,11,17]$. It is also of note that the 1-year and 5 -year survival rates are unfavourable as compared to other tumours, both in men and in women [2].

\section{Discussion}

Colorectal cancer is one of the most important threats to the health of Poles, being the second or third most common cancer and the second or third most common cause of cancer-related death, depending on gender. The increasing trend of negative indicators in long-term analyses and predictions of their continued increase in years to come are alarming. Particularly unfavourable values are recorded in men, in whom the risk of colorectal cancer is higher than in women, as manifested by incidence rates, mortality rates, and 5-year survival rates. The trend is of a longterm character and is clearly marked in the prognoses for the year 2025. The epidemiological situation is also diverse depending on tumour location. The incidence (first cases and peak incidence) of the most common tumour locations, i.e. colon and rectum, is characterised by a trend towards wider distribution across the age axis as compared to the remaining, less common locations. In addition, an opposite, i.e. diminishing trend, is observed for incidence and mortality rates of cancers located within the anus and anal canal in contrast to other locations. The risk of colorectal cancer in Poland is also characterised by diverse dynamics in different regions of Poland, as manifested by differences in positions within the structure of overall cancer incidence and deaths as well as in varied incidence and mortality rates of CRC itself. The distribution of these indicators on the map of Poland is quite interesting. The highest incidence and mortality is observed in residents of Western Poland (Lubuskie, Wielkopolskie, Pomorskie, Kujawsko-Pomorskie, Dolnośląskie, Opolskie Voivodeships). The lowest risk is observed in some regions of Eastern Poland (Podlaskie, Podkarpackie, Lubelskie Voivodeships) as well as of Central Poland (Mazowieckie, Łódzkie Voivodeships).

Considering the fact that lifestyle plays an important role in carcinogenesis and the natural history of the disease, and prognoses are related to society's 
awareness in cancer prevention $[8,11-13,18,19]$, a significant role is also played by tumour diagnostics carried out at early stages of tumour development [1820]. Improvement in the epidemiological situation requires wide-scale interventions in these regions. Health education aimed at modification of lifestyles and adoption of preventive behaviours favouring early detection of pathological lesions may significantly impact the survival of patients. The search for and elucidation of risk factors other than lifestyle also appear to be important. The most recent research in this area is aimed at determination of the effects of environmental changes (pollution), the presence of dioxins, pesticides, or heavy metal salts, both within the environment and in populations [21]. Reduction of the CRC mortality rates would also be associated with improvement of diagnostic methods allowing for the detection of lesions at early developmental stages, as well as with extensive prevention programs.

\section{Conclusions}

The colorectal cancer is a serious threat to the health of Poles, characterised by its dynamics increasing with population age, by high incidence and mortality, as well as by a persistent, constant tendency for increasing epidemiological rates, especially among men. The differentiation of epidemiological rates follows from tumour location. The highest incidence and mortality are registered for tumours located in the colon and rectum. Anal tumours, in contrast to tumours of other locations, show a tendency for decreasing incidence and mortality. Higher incidence and mortality in the population of men, together with worse survival rates, suggest a correlation with higher participation of men in a negative lifestyle, and their reluctance to prophylactic examinations, which all results in late diagnosis. The distribution of incidence and mortality rates in particular regions of Poland shows a higher risk of this tumour for the population of Western Poland.

\section{Conflict of interest}

The authors declare no conflict of interest.

\section{References}

1. Wojtyniak B, Stokwiszewski J, Goryński P, Poznańska A. Długość życia i umieralność ludności Polski. In: Sytuacja zdrowotna ludności polski i jej uwarunkowania. Wojtyniak B, Goryński P, Moskalewicz B (eds.). Narodowy Instytut Zdrowia Publicznego - Państwowy Zakład Higieny, Warsaw 2012; 38-122.

2. Didkowska J, Wojciechowska U, Zatoński W. Nowotwory złośliwe w Polsce w 2011 roku. Centrum Onkologii - Instytut im. M. Skłodowskiej-Curie, Warsaw 2013.

3. Goryński P, Wojtyniak B, Seroka W, Wysocki M. Chorobowość hospitalizowana. In: Sytuacja zdrowotna ludności polski i jej uwarunkowania. Wojtyniak B, Goryński P, Mo- skalewicz B (eds.). Narodowy Instytut Zdrowia Publicznego - Państwowy Zakład Higieny, Warsaw 2012; 128-52.

4. Głuszek S, Zagórska S, Kotucha B. Leczenie żywieniowe chorej z zapaleniem jelita grubego jako powikłanie po radioterapii i chirurgii raka odbytnicy. Studia Medyczne Akademii Świętokrzyskiej 2007; 8: 48-52.

5. Didkowska J, Wojciechowska U, Zatoński W. Prognozy zachorowalności i umieralności na nowotwory złośliwe w Polsce do 2025 roku. Krajowy Rejestr Nowotworów. Centrum Onkologii - Instytut im. M. Skłodowskiej-Curie, Warsaw 2009.

6. Wojciechowska U, Didkowska J, Koćmiel A. Nowotwory złośliwe $\mathrm{w}$ Polsce jako problem zdrowia publicznego. Stud Demograf 2012; 1: 153-66.

7. Siegel R, Naishadham D, Jemal A. Cancer statistics 2013. CA Cancer J Clin 2013; 63: 11-30.

8. Gram IT, Braaten T, Lund E, et al. Cigarette smoking and risk of colorectal cancer among Norwegian women. Cancer Causes Control 2009; 20: 895-903.

9. Wcisło G, Szenajch J, Bodnar L, et al. Rak jelita grubego w świetle współczesnych badań molekularnych. Współcz Onkol 2006; 10: 103-10.

10. Ferlay J, Soerjomataram I, Ervik M, et al. GLOBOCAN 2012 v1.0, Cancer Incidence and Mortality Worldwide: IARC Cancer Base No. 11 [Internet]. Lyon, France: International Agency for Research on Cancer; 2013. Available at: http://globocan.iarc.fr, accessed on 2014.08.10.

11. Wojciechowska U, Didkowska J. Zachorowania i zgony na nowotwory złośliwe w Polsce. Krajowy Rejestr Nowotworów, Centrum Onkologii - Instytut im. Marii Skłodowskiej-Curie. Available at: http://onkologia.org.pl/ raporty/, accessed on 2014.08.06.

12. Huxley RR, Ansary-Moghaddam A, Clifton P, et al. The impact of dietary and lifestyle risk factors on risk of colorectal cancer: a quantitative overview of the epidemiological evidence. Int J Cancer 2009; 125: 171-80.

13. Vogtmann E, Xiang YB, Li HL, et al. Fruit and vegetable intake and the risk of colorectal cancer: results from the Shanghai mens's health study. Cancer Causes Control 2013; 24: 1935-45.

14. Didkowska J, Wojciechowska U, Zatoński W. Nowotwory złośliwe w Polsce w 2010 roku. Krajowy Rejestr Nowotworów. Centrum Onkologii - Instytut im. M. Skłodowskiej-Curie, Warsaw 2012.

15. Zatoński W, Tyczyński J. Nowotwory złośliwe w Polsce w 1996 r. Centrum Onkologii, Instytut im. M. Skłodowskiej-Curie. Krajowy Rejestr Nowotworów, Warsaw 1999

16. Raporty na podstawie danych Centrum Onkologii. Ministerstwo Zdrowia - Narodowy Program Zwalczania Chorób Nowotworowych. Available at: http://epid.coi.waw. $\mathrm{pl} / \mathrm{krn} /$. Accessed on 2014.08.06.

17. Wojciechowska U, Didkowska J. Poprawa przeżyć chorych na nowotwory złośliwe w Polsce. Analiza przeżyć pacjentów zdiagnozowanych w latach 2003-2005. Nowotwory 2013; 63: 279-85.

18. Tuchowska P, Worach-Kardas H, Marcinkowski JT. Najczęstsze nowotwory złośliwe w Polsce - główne czynniki ryzyka i możliwości optymalizacji działań profilaktycznych. Probl Hig Epidemiol 2013; 94: 166-71.

19. Gil J, Stembalska A, Łaczmańska I, Sąsiadek M. Sporadyczny rak jelita grubego - czynniki modulujące indywidualną wrażliwość na zachorowanie. Współcz Onkol 2010; 14: 2011-6. 
20. Olszewska M, Głuszek S. New possibilities for the treatment of gastric cancer. Stud Med 2013; 29: 343-8.

21. Otto W. Trendy w badaniach nad rakiem jelita grubego. Kształcenie Podyplomowe 2012; 2: 7-19.

\section{Address for correspondence:}

Grażyna R. Wiraszka MD, PhD

Department of Internal Diseases,

Cardiology and Medicine Nursing

Institute of Nursing and Obstetrics

Faculty of Health Sciences

Jan Kochanowski University

Al. IX Wieków Kielc 19, 25-317 Kielce, Poland

Phone: +48503072060

E-mail: wiraszka@ujk.edu.pl 